\title{
Seasonal Variation in Population Dynamics of Helminth Parasites in Clarias batrachus from Natural wetlands of Sylhet, Bangladesh
}

\author{
Bari $\mathrm{SM}^{1 *}$, Khalil SMI ${ }^{1}$, Mamun MAA ${ }^{1}$, Islam $\mathrm{MJ}^{2}$, Baten $\mathrm{MA}^{3}$ and Hossain $\mathrm{MM}^{4} \& 5$ \\ ${ }^{1}$ Department of Fish Health Management, Sylhet Agricultural University, Sylhet, Bangladesh. \\ ${ }^{2}$ Department of Aquatic Resource Management, Sylhet Agricultural University, Sylhet, Bangladesh \\ ${ }^{3}$ Department of Fisheries Technology and Quality Control, Sylhet Agricultural University, Sylhet, Bangladesh \\ ${ }^{4}$ Department of Coastal and Marine Fisheries, Sylhet Agricultural University, Sylhet, Bangladesh \\ ${ }^{5}$ Dipartimento di Biologia, Universita' degli Studi di Firenze (University of Florence), Via Madonna del Piano \\ 6, I-50019 Sesto Fiorentino (FI), Florence, Italy
}

[Received: December 04, 2015; Accepted: December 20, 2015]

\begin{abstract}
A year round field investigations were conducted with the aim to examine the seasonal variation in population dynamics of helminth parasites in Clarias batrachus from different natural aquatic habitat of north-eastern region of Bangladesh, Sylhet. This article summarizes the percentage of prevalence, mean intensity, abundance and index of infestation of helminth parasites in the C. batrachus during different months and seasons of the year in accordance with temperature, humidity and rainfall. The investigation period were categorized into four seasons i.e. pre-monsoon (February-April), monsoon (May-July), post-monsoon (August- October) and winter (November- January). A total 180 C. batrachus host individuals were examined and among them 139 (67.87\%) specimens were found to be infested with 2205 individuals of parasites of three different groups namely trematode, cestode and nematode. Almost (100\%) prevalence of helminth infestation were recorded from both male and female C. batrachus during the winter (Nov-Jan), followed by (Feb-April) pre-monsoon (66.67-86.67\%) and (Aug-Sep) post-monsoon (66.67-80.00\%) while lowest $(53.33-60.00 \%)$ in monsoon or rainy season (May-July). Lower range of environmental temperature $\left(21.05-25.05^{\circ} \mathrm{C}\right)$, associated with moderate humidity $(62.00-64.00 \%)$ and scarcity of rainfall increases the intensity of helminthes parasitic infestation in C. batrachus. In consistent to this, with the gradual increasing in ambient temperature (28.01$30.01^{\circ} \mathrm{C}$ ) and humidity $(75.00-89.00 \%)$ associated with moderate rainfall $(33.40-790.90 \mathrm{~mm})$ declining the intensity of helminthes infestation in C. batrachus of the study area.
\end{abstract}

KEY WORDS: Seasonal variation, Population dynamics, Helminth, temperature, Clarias batrachus, Natural wetland

\section{INTRODUCTION}

Walking catfish, Clarias batrachus (Linneaus, 1957) is traditionally popular and important as food fish and widely distributed throughout the South and South-east Asia [1] including Bangladesh considered as an excellent source of good quality proteins and polyunsaturated fatty acids that is why suggested by doctors to pregnant women, lactating mothers, elderly peoples, children and the patient diet [2].These edible fishes are known to harbour a number of parasites which cause deterioration in their health, hence their market and nutritive value is severely affected. The most severe limiting factors in culture and management are diseases [3, 4, 5, 6, 7] and parasitic infestations [8]. Parasite is an important factor in fisheries and aquaculture for causing diseases and in many cases responsible for fish mortality $[9,10,11]$. Assessment of infection levels in the host as well as host population provides important information about the success of the parasite life cycle and the severity if its pathogenicity and the effectiveness of host immunity $[12,13]$

Many authors have carried out studies on the helminth parasites and population dynamics of those occurring in piscian hosts and work on different aspects of parasites $[12,14]$. The scientists all over the globe have contributed a lot of work on the helminth parasites in this selected host [15] explained the helminth parasites of $C$. gariepinus (Clariidae) in Lakki lagoon, Lagos, Nigeria [16] studied the intestinal parasites of $C$. gariepinus, recorded new tapeworm, Lytocestus alii species from C. batrachus at Amaravati, Maharashtra, India [17]. However few research has so far recorded in the past concerning the seasonal variation in the population dynamics of helminth parasites incidence i.e. prevalence, mean intensity, abundance and index of infestation in C. batrachus from the natural waters of Bangladesh. So, the present research work has aimed to investigate the seasonal variation in population dynamics of helminth parasites in $C$. batrachus during different seasons in accordance with temperature, humidity and rainfall from natural wetlands of north-eastern region i.e. Sylhet basin, Bangladesh.

\section{MATERIALS AND METHODS}

Study area and Sample collection: A total $180 C$. batrachus (15 in each months) were collected from different fish markets of Sylhet namely Majortila, Batashor, Bandhar, and Kazir bazaar, which were harvested from flood plains and haors of north eastern region, Bangladesh (Fig. 1) throughout the year starting from February, 2014 up to January, 2015. Monthly mean temperature $\left({ }^{\circ} \mathrm{C}\right)$, humidity were measures by using Silver Indoor Digital Thermometer \& Hygrometer (LC Technology 302-604S) and rainfall $(\mathrm{mm})$ data from the meteorological department and investigate their influence on the rate of incidence, prevalence, and infestation.

Parasitological investigation: After collection of the specimens, they were brought to laboratory, autopsied, and examined for helminths infestation by using standard methods. Endo-helminth parasites were collected, washed with saline solution and preserved in $10 \%$ formalin solution. Then stained with Grenacher's Alcoholic Borax 
Carmine, dehydrated, cleared in xylene, mounted in DPX, processed to a permanent slide and identified under a compound microscope while drawings are made with the aid of camera lucida. The identification of the collected parasites was made with the help of "Systema Helminthium" vol. II. "Cestode of vertebrates" [19, 20, 21, $22,23]$ and population dynamics of cestode parasites were determined by using following formulae.

i. Prevalence $(\%)$

$\frac{\text { No. of host fishinfested }}{\text { No. of host fish examined }} \times 100$

ii. Mean Intensity

No. of the parasites collected

No. of the infested hosts

iii. Abundance

No. of the parasites collected No.of the hosts examined iv. Index na. of host infected xNo.of parasite collected

(No of host examined)

Statistical analysis: Data interpretation was done by using MS excel and SPSS 17 (Chicago, USA) software performed to detect the significance differences.
The morphological, physiological and ecological factors affect the host specificity. The morphological factors are those which like a parasite with its host at the site of attachment [24]. The ecological factors means distribution and environment of the host and physiological factors means the diet and mode of feeding [25, 26] also explained the distribution of parasites are host specific.

The present investigations revealed that the temperature, humidity, and rainfall has strong influence on the prevalence, mean intensity, abundance and index of infection of endo-helminth parasites occurring in $C$. batrachus (Table 2). Comparatively low infestation were recorded in the months of April to June with comparatively high ambient temperature $\left(27.85-28.08^{\circ} \mathrm{C}\right)$, moderate humidity (53.00-82.00\%) and high rainfall (117.30-741.30 $\mathrm{mm}$ ), followed by the months of July to October with high temperature $\left(28.01-30.01^{\circ} \mathrm{C}\right)$ and humidity $(75.00-89.00 \%)$ and moderate rainfall $(33.40-790.90 \mathrm{~mm})$ existed in the study area (Table 2). The incidence of prevalence was highest in the month of November, December and January with low temperature $\left(21.05-25.05^{\circ} \mathrm{C}\right)$; moderate humidity $(62.00-64.00 \%)$ and no rainfall were exhibited in the study area (Table 2). This attributed that tolow environmental temperature, moderate humidity and scarcity of rainfall favored the incidence of helminths infection in the $C$. batrachus.

The low environmental temperature during the months of

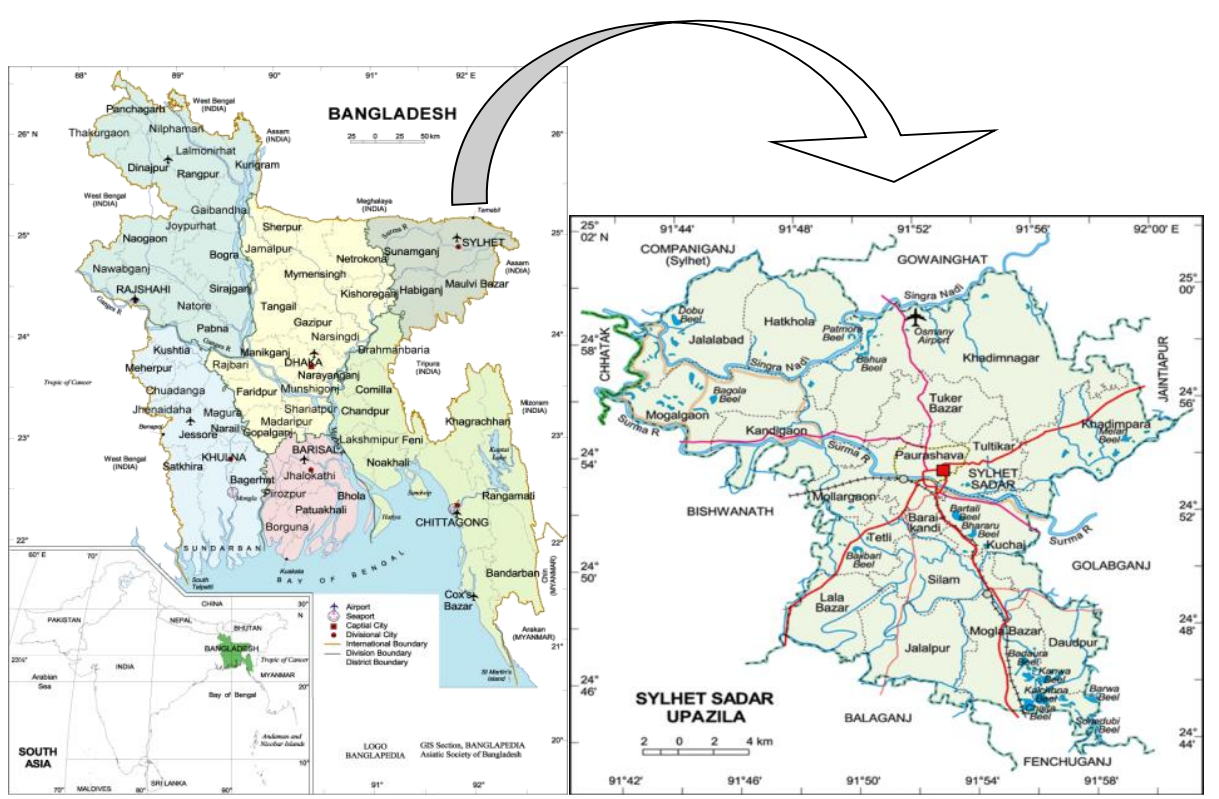

Fig. 1. Showing geographical location of the study area located at Sylhet, Bangladesh [18]

\section{RESULTS AND DISCUSSION}

The present research indicates that out of $180 \mathrm{C}$. batrachus, $139(67.87 \%)$ were infested with 2205 helminth parasites individuals (Table 1). Almost (100\%) p revalence of helminth infestation were recorded from both male and female $C$. batrachus during the winter (Nov-Jan), followed by (Feb-April) pre-monsoon (66.67-86.66\%) and (AugSep) post-monsoon $(66.67-80.00 \%)$ while lowest (53.33$60.00 \%$ ) in monsoon or rainy season (May-July) (Fig. 2). Somehow similar finding also reported from $[12,14]$ and $136(45.33 \%)$ individuals of cestode parasites were recovered from 300 C. batrachus in Aurangabad, India [13].

Present investigation revealed that the morphological, physiological and ecological variables has significantly influence in the occurrence and distribution of helminthes parasitic infestation in C. batrachus (Table 1-2 \& Fig 2).
November to January associated with high relative humidity may be the possible causes of high parasitic intensity during winter. The high intensity of diseases and mortality of fishes winter seasons due to colder temperature and other water quality parameters in Bangladesh were long been reported [10, 3, 27, 28]. Temperature, feeding habits of host, availability of infective intermediate hosts and parasite maturation are known to be significantly influencing incidence of the parasite infection [25].

\section{CONCLUSION}

Findings of the current study suggested that the high infection (level of prevalence, incidence, intensity, density and infection index) of helminth parasites in C. batrachus were occurred during the months of November, December 
Table 1.Incidence, density, prevalence, intensity, abundance and infection index of helminthes parasites in the population of $C$. batrachus from study area.

\begin{tabular}{|c|c|c|c|c|c|c|c|c|}
\hline $\begin{array}{c}\text { Months of the } \\
\text { year }\end{array}$ & $\begin{array}{l}\text { Seasons of } \\
\text { the year }\end{array}$ & $\begin{array}{l}\text { No of Host } \\
\text { Examined }\end{array}$ & $\begin{array}{c}\text { No. of } \\
\text { Host } \\
\text { infected }\end{array}$ & $\begin{array}{c}\text { No. } \\
\text { of } \\
\text { Parasite } \\
\text { collected }\end{array}$ & $\begin{array}{l}0 \\
0 \\
\frac{0}{0} \\
\frac{\pi}{0} \\
0 \\
0 \\
0\end{array}$ & 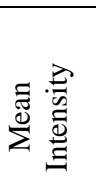 & 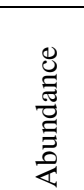 & 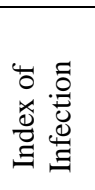 \\
\hline February, 2014 & Pre- & 15 & 13 & 276 & 86.67 & 21.23 & 18.40 & 15.95 \\
\hline March, 14 & Monsoon & 15 & 11 & 194 & 73.33 & 17.64 & 12.93 & 9.48 \\
\hline April, 14 & & 15 & 10 & 302 & 66.67 & 30.20 & 20.13 & 13.42 \\
\hline May, 14 & & 15 & 9 & 195 & 60.00 & 21.67 & 13.00 & 7.80 \\
\hline June, 14 & Monsoon & 15 & 8 & 60 & 53.33 & 7.50 & 4.00 & 2.13 \\
\hline July, 14 & & 15. & 9 & 128 & 60.00 & 14.22 & 8.53 & 5.12 \\
\hline August, 14 & Post- & 15 & 12 & 203 & 80.00 & 16.92 & 13.53 & 10.83 \\
\hline September, 14 & Monsoon & 15 & 10 & 274 & 66.67 & 27.40 & 18.27 & 12.18 \\
\hline October, 14 & & 15 & 12 & 102 & 80.00 & 8.50 & 6.80 & 5.44 \\
\hline November, 14 & & 15 & 15 & 66 & 100.00 & 4.40 & 4.40 & 4.40 \\
\hline December, 14 & Winter & 15 & 15 & 323 & 100.00 & 21.53 & 21.53 & 21.53 \\
\hline January, 2015 & & 15 & 15 & 280 & 100.00 & 18.67 & 18.67 & 18.67 \\
\hline
\end{tabular}

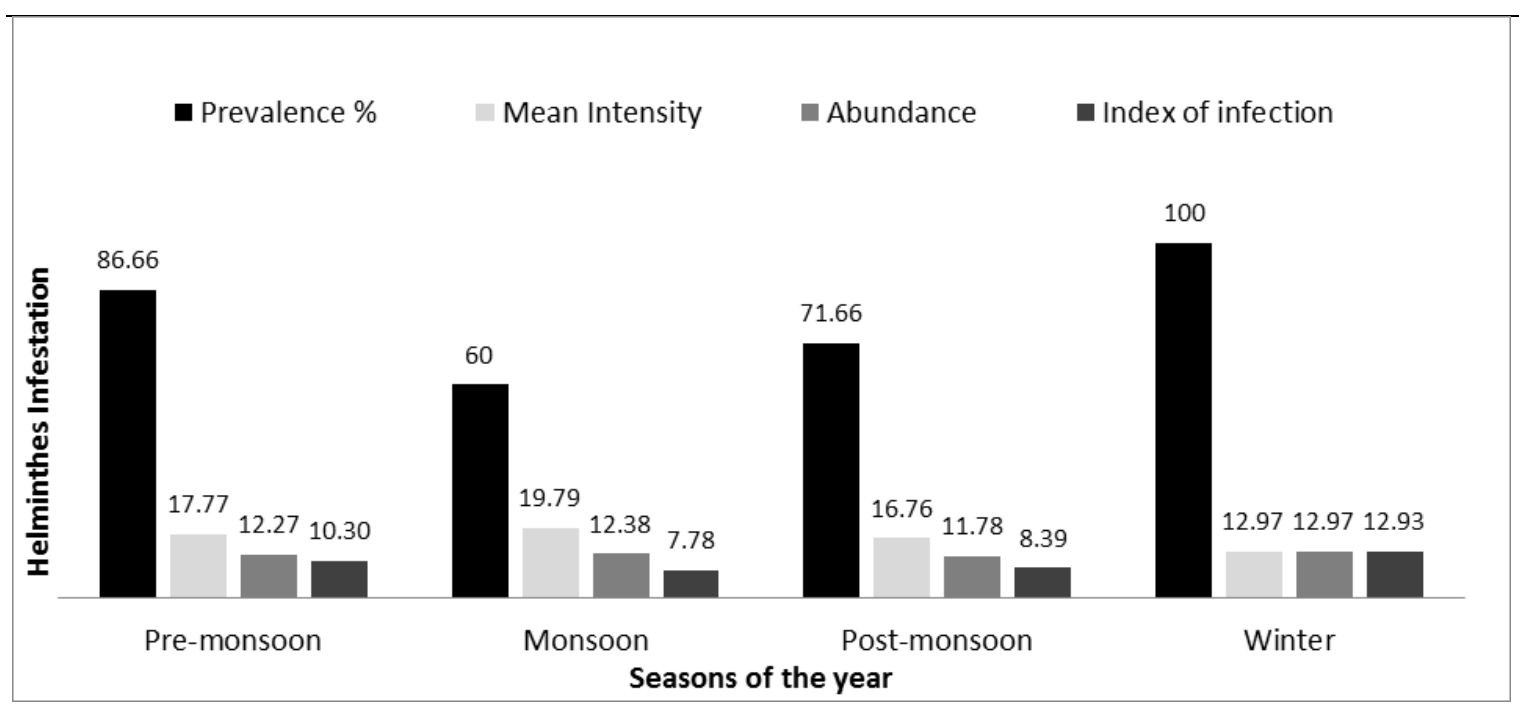

Fig. 2 Seasonal vriation inprevalence, intensity, abudance and infection index of helminths parasites in host $C$. batrachus

Table 2. The influence of temperature, humidity and rainfall on the incidence, intensity, density and index of infection of the helminth parasites occurring in C. batrachus

\begin{tabular}{lccccccc}
\hline $\begin{array}{c}\text { Months of the } \\
\text { year }\end{array}$ & Prevalence & $\begin{array}{c}\text { Mean } \\
\text { Intensity }\end{array}$ & Abundance & $\begin{array}{c}\text { Index of } \\
\text { infection }\end{array}$ & $\begin{array}{c}\text { Temperature } \\
\left({ }^{\circ} \mathrm{C}\right)\end{array}$ & $\begin{array}{c}\text { Humidity } \\
(\%)\end{array}$ & $\begin{array}{c}\text { Rainfall } \\
(\mathrm{mm})\end{array}$ \\
\hline February, 2014 & 86.66 & 21.23 & 18.40 & 15.95 & 20.07 & 62.00 & 34.20 \\
March, 14 & 73.33 & 17.64 & 12.93 & 9.48 & 25.25 & 49.00 & 65.50 \\
April, 14 & 66.67 & 30.20 & 20.13 & 13.42 & 28.25 & 53.00 & 117.30 \\
May, 14 & 60.00 & 21.67 & 13.00 & 7.80 & 27.85 & 72.00 & 540.10 \\
June, 14 & 53.33 & 7.50 & 4.00 & 2.13 & 28.08 & 82.00 & 741.30 \\
July, 14 & 60.00 & 14.22 & 8.53 & 5.12 & 30.01 & 75.00 & 311.40 \\
August, 14 & 80.00 & 16.92 & 13.53 & 10.83 & 29.00 & 82.00 & 790.90 \\
September, 14 & 66.67 & 27.40 & 18.27 & 12.18 & 28.55 & 80.00 & 721.60 \\
October, 14 & 80.00 & 8.50 & 6.80 & 5.44 & 28.01 & 89.00 & 33.40 \\
November, 14 & 100.00 & 4.40 & 4.40 & 4.40 & 25.05 & 64.00 & 0.00 \\
December, 14 & 100.00 & 21.53 & 21.53 & 21.53 & 21.05 & 62.00 & 0.00 \\
January, 2015 & 100.00 & 18.67 & 18.67 & 18.67 & 20.01 & 66.00 & 0.00 \\
\hline
\end{tabular}

and January i.e. winter whereas lowest in monsoon might be associated with the lower temperature, moderate humidity and scarcity of rainfall in winter season. Though present findings depicted contour of helminthes infestation 
in C. batruchus however there might be a high possibilities to transfer endo-parasites to human food chain and associated impact pathways on human health need to be investigate in future.

\section{ACKNOWLEDGEMENT}

Thankful acknowledgement to Dr. Muhammad Anamul Kabir, Department of Aquaculture, Faculty of Fisheries, Sylhet Agricultural University for his cordial co-operation during data analysis of research work.

\section{REFERENCES}

1. $\mathrm{Ng} \mathrm{HH}$ and Kottelat M (2008). The identity of Clarias batrachus (Linnaeus, 1758), with the designation of a neotype (Teleostei: Clariidae). Zool. J. LinneanSoci. 153(4): 725-732.

2. Debnath S (2011). Clarias batrachus, the medicinal fish: An excellent c \&idate for aquaculture \& employment generation. In: International Conference on Asia Agriculture and Animal. IPCBEE (13), Singapore, Pp. 32-37.

3. Hossain MM, Ahmed GU, Ferdous MJ, Khalil SMI, Bari SM, Hassan MM and Gosh K (2014). Seasonal variation of clinico-pathological changes of a farmed exotic carp Hypophthalmichthys molitrix from NorthEastern region, Bangladesh. Annals of Veterinary and Animal Science, 1(3): 122-135.

4. Kashem MA, Uddin MN, Hossain MM, Hasan MT, Haque SA, Khan MNA, Hassan MM and Hossain FMA (2014). Effect of Oxytetracycline on bacterial load of Labeo rohita (Rohu) fish in culture pond. Glo. Adv. Res. J. Microbiol. 3(2): 018-024.

5. Iqbal MM, Kabir MA, Alan CB, Mamun MAA and Hossain MM (2011). Seasonal status of white spot syndrome virus in broodstocks, nauplii and postlarvae of black tiger shrimp (Penaeus monodon) in Bangladesh. I.J Natur. Sci. 1(3):56-61.

6. Ahmed GU, Akter MN, Nipa SA andHossain MM (2009a). Investigation on health condition of a freshwater eel, Monopterus cuchia from AileeBeel, Mymensingh, Bangladesh. J. Bangladesh Agril. Univ. 7(2): 419-424.

7. Hossain MM, Ahmed GU,Tazri Z, Haque MA and Akter MN (2009a). Health status of a snakehead, (Channa punctatus) of two fish marketsin Mymensingh, Bangladesh. Banglades J. Fish. Res.13(1): 11-17.

8. Kabata Z (1985). Parasites and diseases of fish cultured in the tropics. Taylor and Francis Ltd. 318 pp.

9. Caira JN and Littlewood DTJ (2001). Worms, Platyhelminthes. Encycl. Biodiver. Vol. 5. Academic Press. San Diego, California. 863-899.

10. Hosain MT, Ahmed GU, Hassan MM, Kashem MA, Alam MMM and Hossain MM (2014). Health status of eels from open waters: a clinical and histopathological approach. Annals of Veterinary and Animal Science, 1 (1): 30-38.

11. Ahmed GU, Hossain MM and Hassan MM (2009b). Seasonal variation of disease and pathology of a perch, Nandus nandus (Hamilton) from oxbow-lake fisheries of Bangladesh. Eco- Friendly Agril. J.2 (8): 761-767.
12. Chhanda MS and Chandra KJ (2011). Caryophyllaeid infestations on the sex and size of Walking Catfish Clarias batrachus. Bang. J. Anim. Sci. 40(1-2): 5659.

13. Borde SN and Jawale SS (2012). Population Dynamics of Caryophyllidean Tapeworms in Clarias batrachus From Aurangabad District (M.S.) India. Trends in Parasitology Research. 1(1): 25-28.

14. Bari SM, Khalil SMI, Mamun MAA, Hossain MM, Marine SS and Hossain MM (2014). Seasonal Variation and Effects of Helminth Infestation on Clarias batrachus (Linneaus, 1957) from Haor Basin of Sylhet Region, Bangladesh. J. Sylhet Agric. Univ. 1 (2): 231-237.

15. Akinsanya B and Otubanjo OA (2006). Helminth Parasites of Clarias gariepinus (Clariidae) in Lekki Lagoon, Lagos, Nigeria. Rev. Biol. Trop. 54: 93-99.

16. Aliyu MD and Solomon JR (2012). The Intestinal Parasite of Clarias gariepinus Found At Lower Usman Dam, Abuja. Researcher, 4(9):38-44.

17. Sawarkar BW (2012). Record of New Tapeworm, Lytocestus Aliin. sp. from Freshwater Fish Clarias batrachus (Bleeker 1862) at Amravati, Maharashtra, India. J. Biol. \& L. Sci. 3(3.1): 281-287.

18. Banglapedia (2015). National Encyclopedia of Bangladesh. Asiatic Society of Bangladesh, Dhaka, Bangladesh.

19. Yamaguti, S. 1959. The cestodes of vertebrates. Sestema Helminthus Vol. II. Interscience Publishers.Inc. New York, London. 860 pp.

20. Mackiewicz J S. (1982). Caryophyllidean (Cestoidea): Perspectives. Parasitology.84: 397-417.

21. Hafeezullah M (1993). Caryophyllidean Cestode Fauna of India. Records of the Zoological Survey of India, Occasional paper No. 157, 101 pp.

22. Chandra KJ (2008). A Practical Text Book of Fish Parasitology and Health Management. The Bangladesh University Grants Commission, Agargaon, Sher-e-Bangla Nagar, Dhaka, Bangladesh. 213p.

23. Ash A, Scholz T, Oros M and Kar PK (2011). Tapeworms (Cestoda: Caryophyllaeidea), Parasites of Clarias batrachus (Pisces: Siluriformes) in the Indomalayan Region. J. Parasitology,97(3): 435-459.

24. Agrawal et al. (2006). Monogenean helminth parasites - A class of animal class apart. Proc 93rd Ind. Sci. Cong. Hyd. 1-18.

25. Kennedy CR (1976). Ecological aspects of parasitology. North Holland publishing company.

26. Jadhav BV and Bhure DB (2006). Population dynamics of Helminth parasites in freshwater fishes from Marathwada region (M.S.) India. Flora and Fauna International Research Journal, 12(2): 143-148.

27. Hossain MM, Ahmed GU, Tazri $Z$ and Haque MA (2009b). Clinical and pathological investigation of diseases in some small indigenous species (SIS) from fish markets of Mymensingh. Intel. J. BioRes.7(3): 16.

28. Ahmed GU, Hossain MM and Hossain MS (2009c). Histopathology of diseases of an air breathing teleost, Anabas testudineus (Bloch) from freshwater fisheries of Bangladesh. Int. J. Sustain. Agril. Tech.5 (4):75-81. 